\title{
Assessment, Implication, and Analysis of Online Consumer Reviews: A Literature Review
}

\author{
Oshin Anand \\ Indian Institute of Management Rohtak \\ M.D University Campus, India \\ Oshin.anand@yahoo.co.in \\ Praveen Ranjan Srivastava \\ Indian Institute of Management Rohtak \\ M.D University Campus, India \\ praveen.ranjan@iimrohtak.ac.in \\ Atanu Rakshit \\ Indian Institute of Management Rohtak \\ M.D University Campus, India \\ atanu.raks@gmail.com
}

\begin{abstract}
The onset of e-marketplace, virtual communities and social networking has appreciated the influential capability of online consumer reviews (OCR) and therefore necessitate conglomeration of the body of knowledge. This article attempts to conceptually cluster academic literature in both management and technical domain. The study follows a framework which broadly clusters management research under two heads: OCR Assessment and OCR Implication (business implication). Parallel technical literature has been reviewed to reconcile methodologies adopted in the analysis of text content on the web, majorly reviews. Text mining through automated tools, algorithmic contribution (dominant majorly in technical stream literature) and manual assessment (derived from the stream of content analysis) has been studied in this review article. Literature survey of both the domains is analyzed to propose possible area for further research. Usage of text analysis methods along with statistical and data mining techniques to analyze review text and utilize the knowledge creation for solving managerial issues can possibly constitute further work.
\end{abstract}

Keywords: Online Reviews, E-Commerce, Text Analysis, E-WOM, Online Marketing

Citation: Anand, O., Srivastava, P. R. and Rakshit, A. (2017). "Assessment, Implication, and Analysis of Online Consumer Reviews: A Literature Review," Pacific Asia Journal of the Association for Information Systems, 9(2), pp. 43-74. 


\section{Introduction}

Online Consumer Reviews (OCR) has attracted researchers across multiple domains in management and technology. One domain contributes to the importance and implications that reviews have on business environment whereas the other contributes majorly with methodologies to analyze text data. This article attempts to explore both the domains and finally conclude literary lacunae in these domains. Further, the review explores the merger of the two areas and conclude a conceptual model that can add to management literature and highlight areas for further research.

Online Consumer Reviews Is a concept similar to the traditional Word of Mouth, is eword of mouth or online consumer reviews, which is defined as "any positive or negative statement made by potential, actual, or former customers about a product or company, which is made available to a multitude of people and institutions via the Internet" (Hennig-Thurau, Gwinner, Walsh, \& Gremler, 2004). The author besides defining E-WOM, capsuled literature on the factors that lead to the existence of word of mouth as a concept which includes major contributions by Dichter (1966); Engel, Blackwell, \& Miniard (1995); Sundaram, Mitra, \& Webster (1998). Further, deriving from the concept of utility as proposed by Balasubramanian \& Mahajan (2001), the authors concluded the reason for existence of E-WOM, extending prominent factors stated for WOM and the contrast e-WOM has from it (origin; for WOM source is close family and friends; for E-WOM, unknown individual opinions are portrayed in the text.).

Dichter (1966) work on word of mouth listed four dimension relative to the concept: selfinvolvement (gratification of emotional needs from the product), other involvement (a need to give something to the person receiving the WOM transmission), and message involvement (talk that is stimulated by the way the product is presented in media) and, behavior: perceived product- involvement. Addition to this list work, Sundaram et al.(1998) lists eight major drivers (four negative and four positives) for WOM behavior: self-enhancement, vengeance, advice seeking, helping the company, negative WOM altruism, altruism, product involvement, and anxiety reduction.

In recent years, there has been constant growth in the research interest, examining the diffusion of product information through online word-of-mouth. Product review websites, discussion forums, blogs, and virtual communities, are the online platforms where consumers share product reviews. These forums draw parallel to word of mouth and cater similar functionality as WOM communications that previously was confined only to family, friends or relatives (Godes et al., 2005). The large-scale experience-sharing among consumers in these networks potentially reduces uncertainty of the product know how, specifically, about the quality of products or services, that cannot be reviewed before purchase and therefore plays a substantial role in the decision-making of the consumer while purchasing a product online.

Statistics too back the reliance on consumer decision making on OCR. Almost two-thirds of consumers read consumer-written product reviews on the Internet, as stated in a survey by Deloitte's Consumer Products group (Delloite, 2007). Further, consumers who read reviews, 82 percent say their purchase decisions have been directly influenced by the reviews and 69 percent have shared the reviews with their circle( friends, family, or colleagues), thus intensifying their impact. Various consulting reports and surveys have also depicted that for some consumers and products (not generalized for any kind of product and every consumer), consumer-generated reviews are more cherished than expert reviews (ComScore, 2007; Piller, 1999). OCR(Online Consumer Reviews) impact their decision-making process more than the traditional media, and the effects are not only confined to the e-retail but have a 
significant impact on offline purchase behavior as well (ComScore, 2007).

The article is organized as follows; methodology adopted for the assimilated literature, judgmental studies on reviews, and implicational studies on reviews, followed by literature on the textual analysis of reviews.

\section{Methodology}

This work has followed Webster \& Watson (2009) methodology to review the past literature on online reviews. The method stated in Webster \& Watson (2009) emphasizes on the concept driven way of doing the review, where the focus is on author implied concepts from the literature. This allows proper clustering of the plethora of work done in the study field, thereby producing a relevant output of the review. The method suggests literary analysis, concluded with a proposition of a conceptual framework that can aid in future academic research.

"online reviews", "product reviews", "online recommendations", "online word-of-mouth" e-WOM, "online viral marketing", "online consumer reviews", "online communities", and "virtual communities" are the keyword that have been used to procure articles from various management journals and databases like "MIS Quarterly", ABI informa ProQuest, EBSCOhost, Information System Research, Management Science, Electronic Commerce Research, Internet Research, Association of information systems, Decision Support System, Information Management, Journal of Interactive Marketing, Journal of Consumer Psychology, and IEEE Intelligent Systems, Expert Systems and Application along with many others. Besides, research articles from conferences ( $23 \%$ of total collected articles) have also been included in this assimilation of research articles rendering a total of 130 (110 journal articles, 20 conference papers) papers. The table below provides the descriptive of the journals from where the literature has been taken.

The article follows the framework to assimilate literature from two domains, depicted in the diagram below.

This assimilation is attempted by clustering the literature broadly into OCR assessment and OCR implication. Research articles on OCR assessment majorly study the importance of reviews (text) and study of its review components and attributes. The OCR implicational studies talk about the impact of review and its properties on various parameters, which are generally outcome parameters like sales, marketing strategy etc.

Besides contribution from management literature, OCR has also been a researched subject in the technical domain. Researchers contribute on methodologies for analyzing text data. Literature review on OCR hence remains incomplete without the inclusion of literature on mentioned research. Majorly two streams of research articles constitute the opus: text analysis (text mining and sentiment analysis) and content analysis.

A preliminary review of objectives of the research articles renders two broad heads into which the opus on OCR is clustered. The first set majorly constitutes studies that assess OCR relevance and study of its attributes, performance measure and enhancers of review performance. The second set of study are the ones talking about the impact of reviews and its properties on various outcome parameters. The third heading discusses research carried out to contribute various methods in which review text can be analyzed and also study the application of these methods in certain domains. Forthcoming sections would elaborate on research contribution in each of the above-mentioned categories and finally analyzed literary lacunae for future research. 


\section{Table 1 - Sources of Research articles included in this study}

\begin{tabular}{|c|c|}
\hline Decision Support Systems & 14 \\
\hline Journal of Interactive Marketing & 13 \\
\hline Expert Systems with Applications & 6 \\
\hline Information Systems Research & 4 \\
\hline Electronic Commerce Research and Applications, & 3 \\
\hline Electronic Markets & 3 \\
\hline Tourism Management & 3 \\
\hline International Journal of Electronic Commerce & 3 \\
\hline Computers in Human Behavior & 2 \\
\hline International Journal of Machine Learning and Cybernetics. & 2 \\
\hline Journal of Business Research & 2 \\
\hline Journal of Computer Information Systems & 2 \\
\hline Journal of Consumer Research & 2 \\
\hline Management Science & 2 \\
\hline Marketing Letters & 2 \\
\hline African Journal of Business Management & 1 \\
\hline $\begin{array}{l}\text { Annals of Tourism Research, Business Intelligence Journal, Computer Intelligence, } \\
\text { Computational Linguistics, Consumer Research, Discourse, Context \& Media, Electronic } \\
\text { Commerce Research, European Journal of Information Systems, European Journal of } \\
\text { Marketing, Harvard Business Review, Information \& Management, Information and } \\
\text { Communication, Information Systems and E-Business Management, International Journal of } \\
\text { Business and Management, International Journal of Engineering Research and General } \\
\text { Science, International Journal of Forecasting, International Journal of Management and } \\
\text { Marketing Research, International Journal of Trade, Economics, and Finance,, International } \\
\text { Journal on Interactive Design and Manufacturing, Internet Research, Journal of Broadcasting \& } \\
\text { Electronic Media, Journal of Business, Journal of Consumer Psychology, Journal of Information } \\
\text { Science, Journal of International Technology and Information Management, Journal of Marketing } \\
\text { Research, Journal of Retailing, Journal of the Association for Information Systems, Management } \\
\text { Decision, Marketing Intelligence Review, Procedia Computer Science, International Journal of } \\
\text { Advanced Research in Computer Engineering \& Technology, Acta Polytechnica Hungarica, } \\
\text { Cornell Hospitality Quarterly, Strategic E-Commerce Systems and Tools for Competing in the } \\
\text { Digital Marketplace, International Journal on Recent and Innovation Trends in Computing and } \\
\text { Communication, Information and Communication Technologies in Tourism, Journal of } \\
\text { Theoretical and Applied Electronic Commerce Research, International Journal of Science and } \\
\text { Research, International Journal of Hospitality Management, International Journal of Trade, } \\
\text { Economics and Finance }\end{array}$ & 1 \\
\hline
\end{tabular}




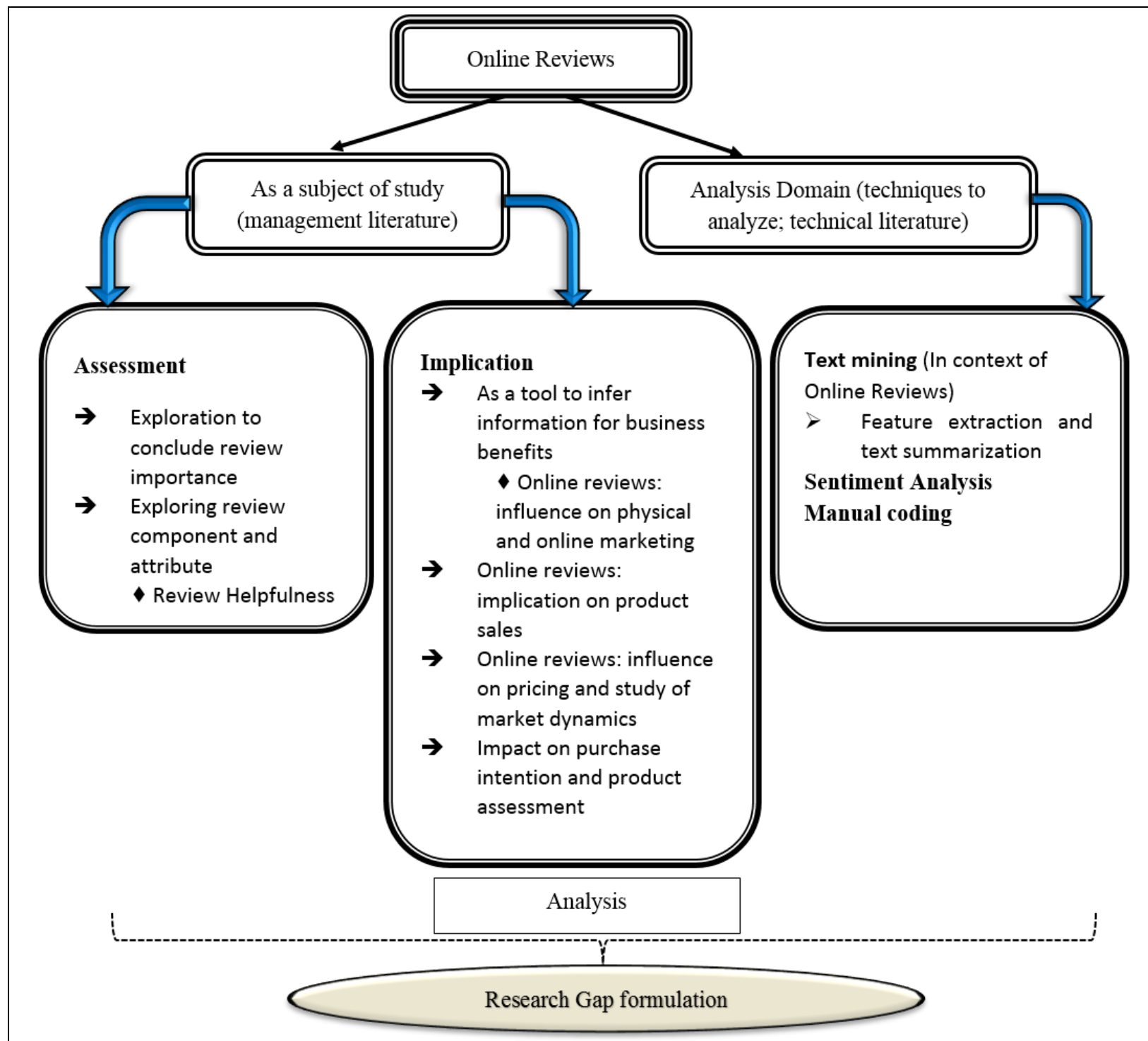

Figure 1 - Framework adopted for conducting the literature review

\section{OCR Assessment}

These set of studies aimed at exploring review text importance and studying their impact on various parameters. Further, this section assimilates studies on different review attributes, of which review helpfulness is detailed as it is studied vividly in the literature.

\section{Exploration to Conclude Review Importance}

Research on online reviews has tried to explore the impact of reviews besides ratings. Their usefulness is studied in various context as stated below.

Gordon, Gu, \& Lin (2006) studies and concludes the prominence of online consumer reviews and their influence on public opinion. Hence, good indicators to customer sentiment and preference and germane to the product or service companies. Gretzel (2008) studies how are consumer reviews used by customers, specific to hotel reviews. The authors conclude its usage to get information from the reviews and not make en route decisions. The credibility of online reviews 
was tested by (Cheung, Sia \& Kuan, 2012). The authors inspect, argument quality, source credibility, review sidedness, review consistency, reviewer's expertise and importance as antecedents to review credibility, for which the data was collected through a survey. Prominence and relevance of WOM marketing established in (Trusov, Bucklin, \& Pauwels, 2010). The authors draw a contrast between WOM marketing and traditional marketing actions to prove the superiority of the former in monetary terms, thus establishing its relevance.

Judgmental studies on reviews have been done from the perspective of reviewers and consumers.

Researchers have studied the motives and motivation that drive consumers to contribute e-WOM. Cheung \& Lee (2012) explores reputation, reciprocity, the source of belonging, enjoyment in helping and moral obligation as some possible antecedents that motivate to contribute online content. Amongst these parameters, reputation, the source of belongingness and enjoyment in helping come out as significant motivators. Chatterjee (2001) studied the reasons for using online WOM from consumers' perspective. The author concluded that e-WOM help consumers to select online retailer. Besides the e-WOM impact on reliability and purchase intention is also moderated by the type of retailer.

Certain review properties were explored to justify the relevance of OCR.

Hao (2010) explores the impact of review property, valence on the consumer decision making with moderation of product type (search or experience), whose significant impact justifies the relevance of text reviews in the purchase decision of the customer. Sen \& Lerman (2007) studies the usefulness of online reviews, in the context of product type and the valence of the text. The author hypothesizes on the negative bias and tests whether positive or negative valence is perceived more useful given the product type. Product type also moderates the credibility of online reviews along with the source from where it comes (Bae \& Lee, 2011).

\section{Exploring Review Component and Attribute}

The literature has visited many review components to explore its relation in various cases. They have been studied in the context of various outcome variables as well as explored in behavior individually. Valence, volume, quality, style are some of review properties that has discussed in literature.

Sparks, So, \& Bradley (2016) explore how hotels respond to negative online reviews and its perception by the customers. Although the basic objective of the document revolves around the response given by the hotel and the attributes of response, like speed, source, voice or action frame, but the central variable to which reaction is done, is negatively valence online reviews. Chang \& Wu (2014) Study the antecedents to e-WOM adoption by readers, with brand commitment as moderators.

Quantified features of reviews have been assessed by Shen, Li, \& Demoss (2012) to study its impact on perceived quality of the product. Three reviews attributes, valence polarity, valence strength and the social context have been studied to see its impact. Pan \& Chiou (2011) explores the combination of the network source of reviews, the valence of reviews and product type (experienced vs search) to study the perceived trustworthiness of online information. Contextual differences as a review attribute have also been studied and concluded to have a significant impact in perceiving differently valenced reviews (Wulff \& Hardt, 2014). These findings by the author indicate the need of being cautious while interpreting the reviews with respect to context.

Writing style as an attribute of review text with moderation of hedonic or utilitarian products has been studied in Kronrod \& 
Danziger (2013). Their research concluded the presence of moderation by product type, on the impact of figurative language in review text, and found that figurative writing style is influential only in case of hedonic products. Mentioning actions or reactions in the review is another way in which writing style has been captured as a variable in Moore (2015). They see its impact on the attitude predictability of customers for hedonic and utilitarian products. Review properties have also been seen to impact purchase intention of the consumer. Argument quality (informativeness and persuasiveness) of the review text, source credibility, and perceived quality, comes out as a significant factor impacting purchase intention (Zhang, Zhao, Cheung, \& Lee, 2014).

\section{Review Helpfulness}

One of the major review attribute, review helpfulness itself has a large section of literary contribution. Though it is not a property of review constituents but is an aspect that depicts review's impact on the reader. Many factors contributing to review helpfulness has been studied throughout the literature. There are two vivid clusters of work related to review helpfulness; antecedents study of review helpfulness and models that help predict helpfulness score for review we don't know of.

\section{Predicting Review Helpfulness}

The literature on review helpfulness constitutes models developed for dynamic prediction of helpfulness percentage. NgoYe \& Sinha (2014) deploys an RFM model and compare several text regression models to conclude reviewer's engagement characteristics and review text as predictors of review helpfulness. Liu, Huang, An, \& Yu (2008) built a predictive model for review helpfulness, taking writing style, reviewer expertise, and timeliness as predictors in the developed radial basis function. Predictive models on review helpfulness, including product characteristics (list price, sales rank, and retail price) and review characteristics (average rating, no. of reviews, extremity, length of sentences, and length of words) has been developed using back-propagation multilayer perceptron neural network (Lee \& Choeh, 2014). Zheng, Zhu, \& Lin (2013) developed a model trained by helpfulness votes to predict the usefulness of a review in comparison to other standard classification techniques.

\section{Contributors to Review Helpfulness}

Ample studies are done with regard to exploring aspects that enhance or degrade review helpfulness. The literature is summarized below in a tabular notation. 


\begin{tabular}{|c|c|c|c|}
\hline & Article & Variables & Study objective \\
\hline 2001 & $\begin{array}{l}\text { Chen \& Smith } \\
(2001)\end{array}$ & $\begin{array}{l}\text { Community impact has been referred } \\
\text { in the disaggregated analysis of } \\
\text { online reviews influence and } \\
\text { helpfulness }\end{array}$ & \\
\hline 2006 & \begin{tabular}{|l} 
Dellarocas \& \\
Narayan (2006)
\end{tabular} & $\begin{array}{l}\text { Hypothesize on product involvement, } \\
\text { message involvement, self- } \\
\text { involvement, concern for others and } \\
\text { social benefit }\end{array}$ & $\begin{array}{l}\text { Specific to movie reviews, impact on helpfulness } \\
\text { (volume of the review posted), studied in } \\
\text { secondary data, most of the variables positive } \\
\text { significant impact. }\end{array}$ \\
\hline 2011 & $\begin{array}{l}\text { Cao, Duan, \& Gan } \\
\text { (2011) }\end{array}$ & $\begin{array}{l}\text { Basic (pro and cons), stylistic and } \\
\text { semantic (terms ) }\end{array}$ & $\begin{array}{l}\text { LSA technique to find relation in document terms } \\
\text { and document, followed reducing and grouping of } \\
\text { terms to run empirical model(logistic regression) }\end{array}$ \\
\hline 2011 & Schlosser (2011) & $\begin{array}{l}\text { Argument type(one-sided or two- } \\
\text { sided) and review extremity. }\end{array}$ & ANCOVA \\
\hline 2012 & $\begin{array}{l}\text { Purnawirawan, De } \\
\text { Pelsmacker, \& } \\
\text { Dens (2012) }\end{array}$ & $\begin{array}{l}\text { Balance (no. of positive and negative) } \\
\text { and sequence ( the sequence in } \\
\text { which reviews appear) }\end{array}$ & $\begin{array}{l}\text { Perceived usefulness as the dependent variable; } \\
\text { recorded by asking questions "whether found } \\
\text { review useful" }\end{array}$ \\
\hline 2013 & Bosman (2013) & $\begin{array}{l}\text { Length, time, platform, valence, } \\
\text { rating, ex-rating, ex-sentiment }\end{array}$ & $\begin{array}{l}\text { Regression model to study review credibility, which } \\
\text { is captured by review helpfulness }\end{array}$ \\
\hline 2014 & $\begin{array}{l}\text { Alexander \& } \\
\text { Morgera (2014) }\end{array}$ & Sentiment of review & $\begin{array}{l}\text { Sentiment interpreting, sentiment analysis } \\
\text { tool(sentistrength) used to compute the sentiment } \\
\text { of the document }\end{array}$ \\
\hline 2014 & $\begin{array}{l}\text { Liu, Hong, \& Liu } \\
\text { (2014) }\end{array}$ & $\begin{array}{l}\text { Review extremity, length, timeliness, } \\
\text { and reputation }\end{array}$ & Impact on perceived usefulness, for movie reviews \\
\hline 2014 & Filieri (2014) & $\begin{array}{l}\text { The quality of information in the } \\
\text { reviews. Information diagnostics are } \\
\text { further based on source credibility } \\
\text { and information quality }\end{array}$ & $\begin{array}{l}\text { Primary data collection on survey response for } \\
\text { each variable, to conclude what makes reviews } \\
\text { helpful. }\end{array}$ \\
\hline 2015 & $\begin{array}{l}\text { Purnawirawan, } \\
\text { Eisend, De } \\
\text { Pelsmacker, \& } \\
\text { Dens (2015) }\end{array}$ & $\begin{array}{l}\text { Valence; for perceived } \\
\text { usefulness(helpfulness) and attitude } \\
\text { towards product }\end{array}$ & $\begin{array}{l}\text { A meta-analysis is carried out to see how valence } \\
\text { of reviews impact perceived usefulness and } \\
\text { attitude towards a product, moderated by product } \\
\text { type. Negative once conclude t contribute to } \\
\text { usefulness whereas positive sets impact attitude } \\
\text { towards the product. }\end{array}$ \\
\hline 2015 & $\begin{array}{l}\text { Salehan \& Kim } \\
\text { (2015) }\end{array}$ & $\begin{array}{l}\text { Title(length, sentiment, polarity), } \\
\text { Review(length, sentiment, polarity) } \\
\text { and longevity (duration on float) }\end{array}$ & $\begin{array}{l}\text { Title properties have been assessed as } \\
\text { antecedents to readership and others for } \\
\text { helpfulness }\end{array}$ \\
\hline 2015 & $\begin{array}{l}\text { Park \& Nicolau } \\
(2015)\end{array}$ & $\begin{array}{l}\text { Study variable is valence; controls are } \\
\text { reviewer characteristics like identity } \\
\text { disclosure, expertise, reputation; } \\
\text { review properties like elaborateness } \\
\text { and readability }\end{array}$ & $\begin{array}{l}\text { Study with dependent variables; helpfulness votes } \\
\text { and enjoyment votes(collected from specific } \\
\text { website-yelp.com) }\end{array}$ \\
\hline 2015 & Liu \& Park (2015) & $\begin{array}{l}\text { Identity disclosure, expertise, } \\
\text { perceived enjoyment, readability, } \\
\text { length of the review, star rating }\end{array}$ & Usefulness of review is studied \\
\hline 2015 & $\begin{array}{l}\text { Huang, Chen, Yen, } \\
\text { \& Tran (2015) }\end{array}$ & $\begin{array}{l}\text { Word count, reviewer expertise, past } \\
\text { helpfulness record and review } \\
\text { framing }\end{array}$ & $\begin{array}{l}\text { Helpfulness impacted by word count in a } \\
\text { diminishing manner, i.e beyond appoint becomes } \\
\text { non-existent. Reviewer expertise is insignificant } \\
\text { with other two significant }\end{array}$ \\
\hline 2015 & $\begin{array}{l}\text { Casaló, Flavián, } \\
\text { Guinalíu, \& Ekinci } \\
\text { (2015) }\end{array}$ & $\begin{array}{l}\text { The valence of reviews, moderation } \\
\text { of risk attitude of customers. }\end{array}$ & $\begin{array}{l}\text { Perceived usefulness was studied, data collected } \\
\text { from survey on Likert scale, to conclude impact of } \\
\text { negative reviews dominating positive once, well } \\
\text { moderated by risk aversive attitude of customers }\end{array}$ \\
\hline 2016 & Qazi et al. (2016) & $\begin{array}{l}\text { Average no. of concepts, no. of } \\
\text { concepts per review wordiness; } \\
\text { moderated by type of review(regular, } \\
\text { comparative or suggestive) }\end{array}$ & $\begin{array}{l}\text { Manual labeling of for review types and senticnet } \\
\text { was used to assess no. of concepts used in the } \\
\text { sentence on which a regression model is run with } \\
\text { dependent variable, review helpfulness. }\end{array}$ \\
\hline
\end{tabular}




\section{OCR Implication}

The following section gratifies the implication of the online consumer reviews; word of mouth, to business. E-tailers and emarketplace are online replicas of its physical counterparts, both with the common focus customers would bear implications on devising strategies in several spheres of online customer reviews and ratings. The major clusters visible out of the lot are pricing strategies, the effect of sales, marketing strategies, and overlapped interrelationship targeted studies.

\section{Used As a Tool to Infer Information for Business Benefits}

Xiang, Schwartz, \& Uysal (2015) used consumer reviews to find what customers expect from different types of hotels. They employ text analytics to accomplish this task and conclude customer preferences. In the changing times of social media, brand equity (including brand loyalty, brand association, brand awareness and brand image) could possibly be dictated by customers reference of the product and therefore is studied in the literature to conclude on the interrelationship (Severi, Ling, \& Nasermoadeli, 2014). Literary contribution by (Xiao, Wei, \& Dong, 2015) provides IS literature with preference measurement model from consumer reviews. Textual analysis and usage of its outcome in a mathematical model help conclude preference list of customers from online reviews.

\section{Online Reviews: Influence on Physical and Online Marketing}

As a conceptual replica of word of mouth, Chen \& Xie (2008) study the online word of mouth, as content, rich of product attributes. Besides, it constitutes influentially judgmental opinions on the product. It can play a major role in regulating apt communication about the product. In existence of product advertisement, which sends product information to customers through different channels, e-WOM bear adhered information through its textual content. The authors studied to deduce implicative mix of attribute communication to the customer by regulating advertisement information according to the information present in OCR that helps in optimizing profits (both are compliments in the case of low-cost product and substitute in case of costly product). Usage of user generated content for a specific customer at a specific time is added implications of the study. The genre of marketing implications is constituted by (Goes, Lin, \& Yeung, 2014) centering around the concept of human flocking in online communities, where reviews play a relevant role. Community impact has been studied in the disaggregated analysis of online reviews influence and helpfulness (Chen \& Smith, 2001).

\section{Online Reviews: Implication on Product Sales}

The discussed set of disquisition, fall into the strategically relevant implications for organizations. A set of work talks precisely on the impact of online reviews on sales of the product.

Dellarocas, Awad \& Zhang (2004) have extended a benchmark model of revenue forecast with the incorporation of online reviews as additional variable besides prerelease marketing, theater availability and professional critics. The work deduces to have increased the existing accuracy of the model. Similar impact study on sales has been studied by (Zhu, 2010) with product and consumer characteristics as moderators of reviews influence over the output. A section of work includes the analysis of sentiments ( $\mathrm{Hu}$, Koh, \& Reddy, 2014; Yu \& Liu, 2012). Hu et al. (2014) examines rating and reviews separately, where sentiments conclude to directly impact sales, (ratings indirectly impacted sales through its impact on sentiments). The impact ease of access ability and cognitive effort reducing heuristics role in the decision-making process were concluded significant to most helpful and most recent 
reviews. The other visible cluster is that of studies that are inclusive of volume and valence of reviews impact on sales (Blal \& Sturman, 2014; Cui, Lui, \& Guo, 2012). As proposed, both the parameters have been concluded significant. Valence-sales relationship, contrasting product and service quality mentions in review text, has also been explored through multi-facet sentiment analysis and empirical validation to conclude significant impact of review valence (Liang, Li, Yang, \& Wang, 2015). The study concludes the inching impact of service quality mentions above product quality on sales through its review text analysis. The quality of reviews which is found substantial for sales of the product has been studied in Blal \& Sturman (2014). Sales elasticity of a product has been inspected against the review properties(volume and valence) and their impact in Floyd, Freling, Alhoqail, Cho, \& Freling (2014).

Hyrynsalmi et al. (2015) study the impact of valence (numeric) on sales. Gu, Tang, \& Whinston (2013) studies online review valence impact on sales with respect to niche or popular product. They investigate reviews capability to develop long tail information and conclude its inability to do so. Another work specific to hotel industry studies customers rating's impact on sales and conclude positive influence (Ögüt \& Onur Taş, 2012). Duan, Gu, \& Whinston (2008) assess movie reviews impact on box office collection. The sentiment of the review was not found to be a significant indicator but the volume of reviews posted does have an influence. Zhu \& Zhang (2006) specifically studies video games industry, and conclude that OCR has a significant impact on sales of gaming products. Chevalier \& Mayzlin (2006) studies the impact of book reviews on its sales. The authors conclude dominance of negative reviews over positive in the impact magnitude and do suggest the prominence of textual content over the summary ratings. The impact of reviews on sales has also been studied under the moderation of different dimensions of reviewer's identity disclosure (Forman, Ghose, \& Wiesenfeld, 2008). The authors also contribute improved methodology to explore the relationship between reviews and sales. Amongst the moderators of sales and review relationship, external reviews i.e. reviews beyond ecommerce websites have been studied and concluded significant (Zhou \& Duan, 2015). The relationship of reviews with sales has been utilized to develop a forecasting model, that uses review information to predict sales (Schneider \& Gupta, 2016).

There are studies that do not assess sales explicitly, but factors that lead to it. Wu \& Gaytán (2013) studies the impact of online reviews volume on customer's willingness to pay. Customers risk attitude (aversive, neutral or seeking) is taken up as a moderator of this impact.

\section{Online Reviews: Influence on Pricing and Study of Market Dynamics}

Reviews and its properties influence on pricing strategy and other marketing dynamics are accumulated here. These studies further establish the importance of reviews for the business.

Guo, Wang, Song, \& Du (2015); Li \& Hitt (2010); Li, Hitt, \& Zhang (2010) explores pricing strategies of players in the emarketplace in the context of reviews. Although none of them take up textual analytics, but ( $\mathrm{Li}$ et al., 2010) consider valence of the review, in their probabilistic model. Guo et al. (2015) record online information from review along with information gathered from the process of information search online and offline. These information are then modeled in combination for strategic pricing. Li \& Hitt (2010) models for price optimization for two staged buyers online, incorporating the indirect impact of prior period price on ratings, which finally impact the pricing strategy for the post period.

Market dynamics have been captured to improve strategizing for alternatives (duopoly \& monopoly) while modeling, 
which is extensively studied in Kwark, Chen, \& Raghunathan (2014) with respect to retailers and manufacturers. The study concludes of varying impacts of reviews in the upstream competition, inclined towards retailer in case of quality dominance and vice versa in case of product characteristic fit domination.

Dou \& Chen (2015) studies the impact of OCR on channel dynamics. They employ a game theory model to conclude that positive OCRs could reduce the manufacturer's and retailer's profits because of double marginalization in the decentralized channel and therefore lead to overpricing. The case of information asymmetry where the manufacturer receives biased information from OCR has also been studied. They conclude that information asymmetry significantly undermines both manufacturer's and retailer's profit, especially when the manufacturer tries to target a small group of customers with a high price premium.

Cao \& Jiang (2014) explores review comments to decide on free trials of the product. Similarly, Pavlou \& Dimoka (2006) studies the presence of review interacting effect on trust, price premium, and seller differentiation. Preference differs when interpreting ratings and making purchases. The study (Li \& Hitt, 2008) develops a model to inspects how eccentric preferences of early buyers can affect longterm consumer purchase behavior as well as the social welfare created by review systems. The analysis is suggestive to firms who could benefit from altering their marketing to encourage consumers, likely to yield positive reports to self-select into the market early and generate positive word-ofmouth for new products.

\section{Impact on Purchase Intention and Product Assessment}

Whether online reviews conclusively impact the purchase intention or the product absorption is judged on factors which either relates to listed properties of online reviews (such as valence, quality, quantity etc.) or behavioral factors (individual's attitude, intentions, context, culture etc.)

Tian, Chen \& Wang (2014); Koh, Hu, \& Clemons (2010); Park \& Lee (2009); Tian (2013) studies human attribute in the context of reviews that contribute to list of factors impacting the output of $e$ marketplace. Koh et al. (2010) address generalized societal behavior (individualist or collectivist) perception of the reviews by the consumer belonging to the two categories.

A collection of studies highlight role of reviews in assessing the product. The collective analysis of societal traits is prolonged to study of personality traits in Tian, Chen \& Wang (2014). Review attributes, such as quantity, quality; valence can be moderated by individual customer's personality trait, which impacts review discernment along with the improved opinion of the product, thereby benefitting the market. Tian (2013) refutes the presence of differed views in two contextually different countries (America and china) in engaging in writing the reviews online. The set of studies establishes consumer psychological impact on the fruitfulness of reviews.

A separate section of work emphasizes on the properties of e-word of mouth with respect to consumer's purchase decision. Some of the studies are generic which incorporates factors like quality quantity, valence, timeliness, and reputation of the reviewer, of which reviewer's reputation was not concluded to be significant (Shao, Li, \& $\mathrm{Hu}, 2014$; Zhu \& Zhang, 2006). Lee, Park, \& Han (2008) study specific factors like negative valence of the review, in interaction with user involvement, and the quality of the post, correspondingly its impact of the consumer decision making. The impact of negative reviews proportion with respect to total no. of reviews, get moderated from high to low intensity by moderators like customer involvement and quality of reviews. A similar study is done in 
Sidali, Schulzea \& Spiller (2008) highlight the importance of the review content property, review's expertise, style of writing and the source credibility for purchase decision of customers.

Sparks \& Browning (2011) studies various factors related to reviews that possibly impact purchase intention and trust in the product (hotels). The authors test the significance review target (core or interpersonal); overall valence of a set of reviews (positive or negative); framing of reviews (what comes first: negative or positive information); and whether or not a consumer generated numerical rating is provided together with the written text. All the factors have some significance either solely or in interaction with each other like Negative valence review intensifies impact when in larger proportions and framed first, whereas positively framed reviews are related more to interpersonal as the target. Mauri \& Minazzi (2013) take up valence of the reviews, separately hypothesizing for two types of travel websites transactional and non-transactional to study the level of expectation from the while booking hotels online, which was concluded to have positive correlation for the interaction.

Review properties like the level of details mentioned in the review have been studied to impact the purchase intention of the customers, with product type as moderator (Jiménez \& Mendoza, 2013). The authors also include the mediation of review credibility in their research. Review attributes like argument quality (persuasiveness and in formativeness), source credibility and perceived quality of reviews have been studied as influencing antecedents to purchase intention of the customers (Zhang et al., 2014). The influence of e-WOM on buying decision in the context of low-cost carriers has been studied in Lerrthaitrakul \& Panjakajornsak (2014). They study the creditability of channels used, volume of e-WOM; types of e-WOM such as multiple transmission channels, one to many channels, one to one channels and their potential to impact the decision making process in the given context. Purchase intention as the outcome variable to online reviews has been studied under the moderation of contextual difference (Park \& Lee, 2009). The study encircles the impact of consumer characteristics and attitude (customer susceptibility, internet shopping experience and perceived usefulness of reviews) on the usage of online review and purchase intention. This relationship is studied under the contextual moderation of US and Korea and was found significant. Further, studies have explored mediating effect of brand trust dimensions between Online reviews and willingness to buy (Cheng, Rhodes, \& Lok, 2015). The study concludes the relevance of online reviews as well as the need to manage negative ones to prevent damage to brand trust.

\section{Textual Analysis of Online Reviews}

With the proliferation of internet market data, literature has moved from quantitative parameters to qualitative parameters. Although management research still lacks behind the technical research in this domain contribution, specific to review documents, the progress in literary contribution is vivid. Most of the algorithms developed or modified for the purpose focuses on the feature extraction, classification and sentiment mining. Besides, there are two wide streams in this arena: computer aided analysis and manual analysis.

Text mining or text data mining (automated) is old school. It's amplified application in the reviews domain is comparatively recent. The technique has played role in opinion extraction and summarization ( $\mathrm{Hu} \& \mathrm{Liu}$, 2006). This text summarization engulfs text parsing (Archak, Ghose, \& Ipeirotis, 2007, 2011; Hu \& Liu, 2006) with POS tagging used in the above-cited group, along with Aravindan \& Ekbal (2014); Bafna \& Toshniwal (2013); Ingale \& Phursule (2014); Raghupathi, Yannou, Farel, \& Poirson 
(2015). Classification algorithms also find a vivid place in the literature, to meet desired outcomes. Majorly six of them (Chou, Sinha, \& Zhao, 2008); naïve Bayes, K-nearest neighbor, c 4.5 decision tree, support vector machine, back propagation neural net, and artificial neural net have been used in the literature (Archak et al., 2011; Chou et al., 2008; Tang, Tan, \& Cheng, 2009). Apart from these usages, text analysis has been used for product weakness finder (Zhang, Xu, \& Wan, 2012), sarcasm detection (Tsur, Rappoport, \& Davidov, 2010), abuse detection (Chou et al., 2008) and developing a ranking system (Ghose \& Ipeirotis, 2007). For the execution of these objectives, several automated and algorithmic tools have been utilized.

Content analysis, a super-set to text analysis, also has shown presence in reviews literature (Conley \& Tosti-Kharas, 2014; Lewis, Zamith, \& Hermida, 2013; Simmons, Conlon, Mukhopadhyay, \& Yang, 2011). Manual text analysis has also found a place, through crowdsourcing (Archak et al., 2011; Conley \& Tosti-Kharas, 2014) or otherwise (Lewis et al., 2013; Tan, Na, \& Theng, 2011). Besides some work depicts a comparison of manual and computer-aided analysis (Conway, 2006; Simmons et al., 2011), with results depicting pros and cons of both the techniques.

A detailed assimilation of academic contribution in text mining and content analysis is provided below.

\section{Text Mining}

Tang and Guo (2015) does a survey-based study to validate the need for digging textual content beyond the quantitative parameters for deriving valuable information from online reviews. They justify the need and the limited contribution of text analysis in management literature, which can be executed using several available tools in the domain of textual data mining.

An overall summarization of text mining and analysis method is clustered under the following heads; information extraction, topic drilling, categorization, summarization and clustering to derive knowledge from information (Gupta, \& Lehal, 2009). This approach is also backed by Devi \& Kini (2015). They perform a survey on text mining approaches to conclude on similar major step clusters as in (Gupta et al., 2009).

Major contribution to literature can be clustered under two broad heads; feature extraction and sentiment mining. Feature extraction is also appended by sentiment analysis in some cases.

\section{Feature Extraction and Text Summarization}

Literary contribution under this head comprises extraction of information which can be product features or other valuable content. This information gain generates pertinent knowledge that can be utilized by business or customers. Text summarization deals with concluding the algorithmic outcomes of extracted terms or features. Researchers add different ways and methods in which one can conclude significant terms, to the plethora of literature.

$\mathrm{Hu} \&$ Liu (2006) developed an algorithm to categorize text with the help of POS tags and develop patterns using association mining to conclude the sequence of nouns, verbs, and adjectives and therefore the term. Frequent once were then shortlisted to conclude the final set of terms. Term extraction is paralleled with categorization in the case of binary outcomes, such as abuse or non-abuse in Chou et al. (2008). The authors contrast various text classification technique like naïve Bayes, KNN, support vector machine, neural net and decision tree for the categorizing presence of either of the two categories. Further for these terms weights was concluded followed by classification. Aravindan \& Ekbal (2014) uses a combination of association mining and support vector machine, along with part of speech tagging, sentiment computation, feature estimation using plus three minus three vicinities amongst words is deployed to perform feature extraction and opinion 
classification for them. Extraction and summarization of feature are done using both probabilistic and association mining models in Bafna \& Toshniwal (2013). Zheng, Wang, \& Gao (2015) propose a 4-POS gram model of feature extraction and sentiment mapping. The study concludes on its improved accuracy on existing methods. Zhuang, Jing, \& Zhu (2006) mine implicit and explicit feature opinion pair using dependency grammar graph to extract information from customer reviews.

Another set of studies uses text extraction to further assessment. Term extraction conclusion is extended for further analysis in the literature to decipher customer opinion. You, Xia, Liu, \& Liu (2012) devises a weight computing scheme using POS tags to find the prominent terms in the review. These terms are then coded and quantified as plus or minus one according to their placement in pros or cons part of the review document. This quantification is then used to run an ordinal regression with overall rating as the dependent variable to find significant categories. Feature extraction using POS tags followed by feature mining using parse tree sequence and finally sentiment computation using polarization is done to generate recommendation system for electronic products (Ojokoh, 2013). Hongwei, Wei, \& Pei (2014) does term extraction and estimation of its polarity and its strength to find out the weaknesses in a product. They develop a text-mining algorithm to perform feature extraction and sentiment estimation using wordnet. Sardesai, Makwana, \& Haria (2014) contributes a new NLP approach by assigning latent weight to each product feature, thus performing feature sentiment extraction from reviews on a sentence level which is further summarized to depict overall opinion. A different usage of feature extraction (pattern based) is done to identify sarcasm in a book review (Tsur et al., 2010). The authors develop an algorithm for identifying aspects that are sarcastically commented in a review and was apprehended with multiple annotators for tagging the review document. Text analysis of reviews has been carried out to find out the impact of the derived information on outcome tangibles like product sales (Moon, Park, \& Kim, 2014). Text clustering of reviews is followed by determination of estimating relationship with user ratings and finally empirically estimate the impact on sales.

Apart from algorithmic contributions, automated tools have also been used for the purpose of term extraction. Automated tools like SPSS clementine and Nvivo 9 has been used for text categorization, extraction and classification of social media data, which further modeled to identify patterns and conclude relevant result for business (He, Zha, \& Li, 2013). The analysis recommends strategies for pizza industry, taken up in this study, for encashing social media reach. Minanovic, Gabelica, \& Krstic (2014) used KNIME for text mining review and social media data. The article does a comparative study on dictionary development, term extraction considering the noun-adjective presence, absence and sequence, presence of negation and finally grading using frequency and TF-IDF weights. Although the objective of the paper is to present a comparative analysis but they distinctively add to methods for term extraction.

Fan \& Khademi (2014) map rating to textual content, by trying to quantify target from the information in the text. The authors drill out frequent items in three categories; generic, nouns and adjectives and predict stars using linear regression, SV regression (normalized and non-normalized) and decision tree. They assess these four algorithms for prediction using RMSE. Lucas, Nielsen, Roberts, Stewart, Storer, \& Tingley (2015) uses the structural topic model to analyze multilingual text data on comparative politics. The author draws a contrast of this methodology with LDA. Extraction of nouns and adjectives and their relationship has been done in Zhu \& Fang (2014). The authors use this extraction to 
assess the player's experience in video gaming industry.

The book chapter shows how quantitative data technique like association mining can also be used to derive relationships and patterns in qualitative data. (Using Association Rules Mining to Facilitate Qualitative Data Analysis in Theory Building).

\section{Sentiment Analysis}

A state of art on sentiment analysis depicts various levels on with sentiment estimation is carried out, different steps involved in the process, the evolution of these processes and finally set of algorithms that help make any analysis of this kind conclusive (Appel, Chiclana, \& Carter, 2015). They depict that such techniques have the scope of further contribution in the domain of unsupervised learning which is evidently pointed out by existing literature.

There are research articles that use text mining techniques to classify data into different valence. Anthuvan, Dhiviya, Rajeswari, \& Suguna (2015) deploy support vector machine and principal component analysis to perform sentiment analysis on collected and cleaned review data. Kaiser \& Bodendorf (2012) mines online reviews and compares different classification algorithm for sentiment mining. The authors conclude SVM better than others. Further network analysis of the data helps detect the influential nodes. There has been research contribution to summarize problems associated with sentiment classification and explain in terms of its dependency on subjectivity classification, word sentiment classification and document sentiment classification (Tang et al., 2009). Semantic orientation has also been used to compute the polarity and strength of reviews with the inclusion of negation and intensification of sentiment reflecting words (Taboada, Brooke, Tofiloski, Voll, \& Stede, 2011). Sentiment analysis of short documents like reviews has been done in terms of aspects in Thet, Na, \& Khoo (2010). The computation of sentiment score is done by using sentiwordnet and decision tree to decipher clauses containing the aspect in concern for the study. Literary work by Zhang et al. (2012) depicts usage of aspectbased sentiment mining to identify weakness in a Chinese product. The authors propose an algorithm that aims to categorize the reviews based on extracted aspects and henceforth map sentiment to identify the negative orientation of customer towards certain product aspect, specific to the brand. Sentiment analysis of movie review is done to mine opinion polarity using S-PLSA model developed using past sales (Yu \& Liu, 2012).

Sentiment analysis of big data specifically data on online portals has been done using big data tool Hadoop (Revathi, Rajkumar, \& Sathish, 2015). With the wide variety available in the data online, the authors have worked for better classification thus resulting in summarizing neutral category apart from positive and negative. Sentiment analysis of review text has been done based on word dependency. Bai (2011) proposes a heuristic search-enhanced Markov blanket model to accomplish sentiment classification, by using word dependency logic. Raghupathi et al. (2015) did sentiment classification based on heuristics. The authors developed an algorithm using text parsing, followed by usage of a Dictionary of Affect Language to rate word tree leaves and finally a series of basic heuristics to calculate backward an overall sentiment rating for the review. A summarization on the sentiment of review document has also been done by visual examination using opinion seer (Ingale \& Phursule, 2014). The study takes into account several sub-steps to finally get an integrated view of multiple correlations. These correlations allow identifying useful opinion patterns quickly. Furthermore, it enables a visual comparison of opinions of different customer groups. An improved approach for overall sentiment summarization is proposed in Thelwall et al. (2013). The authors compare the output of 
damped and non-damped sentiment conclusion, where damping means adjustment of the sentiment of a sentence according to the average sentiment projection in its vicinity. Ye, Zhang, \& Law (2009) did a comparative study of supervised learning algorithms utilized to classify text. N-gram and SVM outperform naïve Bayes in the results. Bai (2011) devises a mechanism to predict sentiment of online data and contrast with state-of-art methods to depict its improved accuracy. The article proposes a heuristic-search enabled Markov blanket model that helps capture the dependency among words and provide vocabulary efficient enough to categorize sentiments of textual data.

The table below summarizes major methodologies used in the literature:

Table 3 - Literary Contribution: Text Analysis

\begin{tabular}{|c|c|c|c|}
\hline & Author & title & Methods \\
\hline 1999 & $\begin{array}{l}\text { Wong, Whitney, \& } \\
\text { Thomas (1999) }\end{array}$ & $\begin{array}{l}\text { Visualizing association } \\
\text { rules for text mining }\end{array}$ & Association rules \\
\hline 2006 & Hu \& Liu (2006) & $\begin{array}{l}\text { Opinion Extraction and } \\
\text { Summarization on the Web }\end{array}$ & $\begin{array}{l}\text { Nlp processor; } \\
\text { infogistics.com/textanalysis.html }\end{array}$ \\
\hline 2007 & $\begin{array}{l}\text { Agarwal, Godbole, } \\
\text { Punjani, \& Roy (2007) }\end{array}$ & $\begin{array}{l}\text { How much noise is too } \\
\text { much noise: automatic text } \\
\text { classification }\end{array}$ & $\begin{array}{l}\text { Rainbow(bow toolkit) } \\
\text { Multinomial naïve Bayes } \\
\text { SVM }\end{array}$ \\
\hline 2007 & Archak et al. (2007) & $\begin{array}{l}\text { Pricing power on product } \\
\text { features }\end{array}$ & Pos tagging \\
\hline 2007 & Ghose (2007) & $\begin{array}{l}\text { Designing a novel review } \\
\text { ranking system }\end{array}$ & $\begin{array}{l}\text { Pang and lee( review subjectivity and } \\
\text { objectivity) } \\
\text { NB and SVM subjectivity classification }\end{array}$ \\
\hline 2008 & Chou et al. (2008) & $\begin{array}{l}\text { Text mining for internet } \\
\text { abuse detection }\end{array}$ & $\begin{array}{l}\text { Text categorization(NB, decision tree, } \\
\text { SVM, KNN, indexing (TF-IDF), remove } \\
\text { stop words; weka data mining tool }\end{array}$ \\
\hline 2008 & $\begin{array}{l}\text { Strong, Ghosh, \& } \\
\text { Conlon (2008) }\end{array}$ & $\begin{array}{l}\text { Identifying opportunities in } \\
\text { multilingual environment } \\
\text { and text mining }\end{array}$ & $\begin{array}{l}\text { Text categorization, clustering, } \\
\text { extraction, document summarization } \\
\text { (MT/NLP SYSTRAN) FIRST(flexible } \\
\text { information extraction system) }\end{array}$ \\
\hline 2009 & $\begin{array}{l}\text { Ngai, Xiu, \& Chau } \\
\text { (2009) }\end{array}$ & & \\
\hline 2009 & Chen (2009) & $\begin{array}{l}\text { Text Mining e-Complaints } \\
\text { Data } \\
\text { From e-Auction Store } \\
\text { With Implications } \\
\text { For Internet Marketing } \\
\text { Research }\end{array}$ & $\begin{array}{l}\text { TextAnalyst } 2.3 \text { by Megaputer } \\
\text { Intelligence }\end{array}$ \\
\hline 2009 & Tang et al. (2009) & $\begin{array}{l}\text { A survey on sentiment } \\
\text { detection of reviews }\end{array}$ & $\begin{array}{l}\text { Developed a subjectivity classification } \\
\text { model }\end{array}$ \\
\hline 2009 & Ye et al. (2009) & $\begin{array}{l}\text { Sentiment classification of } \\
\text { online reviews to travel } \\
\text { destinations by supervised } \\
\text { machine learning } \\
\text { approaches }\end{array}$ & NB/SVM/n-gram \\
\hline
\end{tabular}


anand et al.: Assessment, Implication, and Analysis of Online Consumer Reviews:

Assessment, Implication, and Analysis of Online Consumer Reviews / Anand et al.

\begin{tabular}{|c|c|c|c|}
\hline 2010 & Li, Lin, \& Lai (2010) & $\begin{array}{l}\text { Identifying influential } \\
\text { reviewer for WOM market }\end{array}$ & $\begin{array}{l}\text { With RFM analysis, firms could } \\
\text { discover the potential and valuable } \\
\text { customers easily by observing their } \\
\text { past behaviors. } \\
\text { the comments written by each reviewer } \\
\text { are first analyzed by text-mining } \\
\text { techniques and quantified by a } \\
\text { modified PMI (Pointwise Mutual } \\
\text { Information) measure based on an } \\
\text { established subjective work set. In the } \\
\text { meantime, the reviewing recency and } \\
\text { frequency of the authors are quantified } \\
\text { to measure the RFM scores of the } \\
\text { reviewers. Then, the PMl- and RFM- } \\
\text { based scores are combined to } \\
\text { determine whether a reviewer has the } \\
\text { infective ability and is valuable in word- } \\
\text { of-mouth marketing. To aggregate } \\
\text { these two scores better, an ANN } \\
\text { (artificial neural network) technique is } \\
\text { used to implement the weighting } \\
\text { mechanism. The well- trained ANN } \\
\text { model further outputs a list of ranked } \\
\text { influential reviewers. Finally, we utilize } \\
\text { a well-developed trust mechanism to } \\
\text { evaluate the effectiveness of our } \\
\text { proposed influential reviewers } \\
\text { discovering mechanism. } \\
\text { NNTool of Matlab for ann }\end{array}$ \\
\hline 2010 & Thet et al. (2010) & $\begin{array}{l}\text { Aspect-based sentiment } \\
\text { analysis of movie reviews }\end{array}$ & $\begin{array}{l}\text { Sentiwordnet ( subjectivity classifier) } \\
\text { entropy gain }\end{array}$ \\
\hline 2010 & Tsur et al. (2010) & Sarcasm detection & Algorithm based \\
\hline 2011 & $\begin{array}{l}\text { Ghose \& Ipeirotis } \\
\text { (2011) }\end{array}$ & $\begin{array}{l}\text { Estimating helpfulness and } \\
\text { economic impact of product } \\
\text { reviews }\end{array}$ & $\begin{array}{l}\text { Subjectivity, readability, spelling } \\
\text { errors(http://www.alias-i.com/lingpipe/) }\end{array}$ \\
\hline 2011 & Archak et al. (2011) & $\begin{array}{l}\text { Driving the pricing power of } \\
\text { product features by mining } \\
\text { product reviews }\end{array}$ & $\begin{array}{l}\text { Amazon mechanical Turk } \\
\text { Pos tagging } \\
\text { Mechanical methods( imprecision) } \\
\text { Bayesian weighting scheme } \\
\text { PMI }\end{array}$ \\
\hline 2011 & Taboada et al. (2011) & $\begin{array}{l}\text { Lexican based sentiment } \\
\text { analysis }\end{array}$ & $\begin{array}{l}\text { The Semantic Orientation CALculator } \\
\text { (SO-CAL) uses dictionaries of words } \\
\text { annotated with their semantic } \\
\text { orientation (polarity and strength) and } \\
\text { incorporates intensification and } \\
\text { negation. }\end{array}$ \\
\hline 2012 & $\begin{array}{l}\text { Robinson, Goh, \& } \\
\text { Zhang (2012) }\end{array}$ & $\begin{array}{l}\text { Textual factors in online } \\
\text { product reviews: foundation } \\
\text { of a more influential } \\
\text { approach }\end{array}$ & Nvivo 8 \\
\hline 2012 & $\begin{array}{l}\text { Kaiser \& Bodendorf } \\
(2012)\end{array}$ & $\begin{array}{l}\text { Mining consumer dialog in } \\
\text { online forums }\end{array}$ & SVM, Knn, NB and polarity extraction \\
\hline 2013 & Halper (2013) & $\begin{array}{l}\text { Text analysis hits } \\
\text { mainstream }\end{array}$ & $\begin{array}{l}\text { Contributes in overall methodology to } \\
\text { analyze text data ( important paper) }\end{array}$ \\
\hline
\end{tabular}


Pacific Asia Journal of the Association for Information Systems, Vol. 9, Iss. 2 [2017], Art. 4

Assessment, Implication, and Analysis of Online Consumer Reviews / Anand et al.

\begin{tabular}{|c|c|c|c|}
\hline 2013 & He et al. (2013) & $\begin{array}{l}\text { Social media competitive } \\
\text { analysis and text mining }\end{array}$ & $\begin{array}{l}\text { SPSS clementine, nvivo 9( cleaning, } \\
\text { assigning attributes, integrating data) }\end{array}$ \\
\hline 2013 & Mostafa (2013) & $\begin{array}{l}\text { Social network consumer } \\
\text { mining for consumer brand } \\
\text { sentiment }\end{array}$ & twitter, Plyer, Striger,ggplot2 \\
\hline 2013 & $\begin{array}{l}\text { Bafna \& Toshniwal } \\
\text { (2013) }\end{array}$ & $\begin{array}{l}\text { Feature-based } \\
\text { summarization of customer } \\
\text { review of online product }\end{array}$ & Stanford NLP parser \\
\hline 2014 & $\begin{array}{l}\text { Aravindan \& Ekbal } \\
\text { (2014) }\end{array}$ & $\begin{array}{l}\text { Feature extraction and } \\
\text { opinion mining for online } \\
\text { product reviews }\end{array}$ & $\begin{array}{l}\text { Pos tagging and feature extraction } \\
\text { Stanford coreNLP parser }\end{array}$ \\
\hline 2014 & $\begin{array}{l}\text { Ingale \& Phursule } \\
(2014)\end{array}$ & Review paper & \\
\hline 2014 & Hongwei et al. (2014) & Prodweakfinder & Product weakness finder \\
\hline 2014 & $\begin{array}{l}\text { Ghode, Bere, Kamale, } \\
\& \text { Moholkar (2014) }\end{array}$ & $\begin{array}{l}\text { Sentiment analysis of } \\
\text { online product reviews ( a } \\
\text { survey) }\end{array}$ & \\
\hline 2014 & Minanovic et al. (2014) & $\begin{array}{l}\text { Big data and sentiment } \\
\text { analysis using KNIME }\end{array}$ & KNIME \\
\hline 2014 & $\begin{array}{l}\text { Sardesai, Makwana, \& } \\
\text { Haria (2014) }\end{array}$ & $\begin{array}{l}\text { Review mining : a new } \\
\text { approach }\end{array}$ & stanfordNLP Parser/ api sentiwordnet \\
\hline 2015 & Anthuvan et al. (2015) & $\begin{array}{l}\text { Real time-based product } \\
\text { mining in online reviews } \\
\text { using supervised learning }\end{array}$ & $\begin{array}{l}\text { Word reference dictionary (Word } \\
\text { Net/Spell-check/Jspell) } \\
\text { Abbreviations and/or shorthand } \\
\text { documentations(Net dialect and SMS } \\
\text { word_used) } \\
\text { Energetic Spell Checker, Jspell and } \\
\text { Snow ball for spell checking. For } \\
\text { Evacuate the stop words. Stanford, } \\
\text { Wiki, and Testifier } \\
\text { SVM/ANN }\end{array}$ \\
\hline 2015 & Revathi et al. (2015) & $\begin{array}{l}\text { Text sentiment approach } \\
\text { for online portals using } \\
\text { Hadoop }\end{array}$ & Hadoop for naïve Bayes classifier \\
\hline 2015 & $\begin{array}{l}\text { Raghupathi et al. } \\
\text { (2015) }\end{array}$ & $\begin{array}{l}\text { Customer sentiment } \\
\text { appraisal using user- } \\
\text { generated product reviews }\end{array}$ & $\begin{array}{l}\text { Stanford NLP core tokenizer } \\
\text { Dependency tree } \\
\text { SENTRAL algorithm }\end{array}$ \\
\hline 2015 & Zheng et al. (2015) & Chinese reviews & $\begin{array}{l}\text { N-Pos-gram, N-char-gram } \\
\text { Document frequency }\end{array}$ \\
\hline
\end{tabular}

\section{Manual Coding}

A comparison between manual codes and computer-aided coding concludes the subjective precision of the machines to derive the actual meaning from the text (Conway, 2006). The author highlights the need of adding subjective precision to get information from the text. The article suggests the use of sophisticated programs in assistance with manual codes to get meaningful knowledge from the textual information. Simmons et al. (2011) used CAINES (content analyzer and information extraction system) to extract terms. The methodology involved POS tagging and feature extraction using lexicon defined with help of manual rators. Bazeley (2012) study how qualitative coding can be facilitated using Nvivo, which help increase accuracy and speed of manual codes. 
Lewis et al. (2013) uses a combination of manual and automated approach to analyze text data on twitter, and conclude the advantages of using a hybrid approach. The authors depict how a combination of the methodology speed up the task with accuracy in case of automated analysis and contextual inferences improved using manual approach.

\section{Discussion and Conclusion}

This review article aimed at assimilating literature related to online consumer reviews from various perspective. Each of these dimension in which academic contribution are synthesized, depict the vast knowledge creation in this area. Analyzing each of these angles in isolation and in togetherness indicate the further scope of research such as

$>$ Further exploration of factors involved in review performance measure, utilize text analysis in in depth extraction of detailed factors related to review's influential capacity.

> Developing a business recommendation model though pattern recognition

$>$ Analysis of review text on sentence level, in contrast to majorly explored document level

$>$ utilizing a multi-method approach; like

- text mining techniques, feature extraction and quantification

- statistical modelling

- data mining

Extensive studies around online reviews indicated the importance of the text data content that was being collected online apart from a rating of the product. It is indicated how various attributes of online reviews reacted and behaved in a different context. This difference in behavior affects consumer information gathering and purchase decision.
One of review attributes, Helpfulness has gathered major attention in management literature. Various antecedents to review helpfulness were studied and significant once were concluded. Helpfulness can act as a parameter to review a judgment by the customer and therefore indicate review performance. The basic intention of text reviews is to communicate about the product in an unbiased manner, and hence help make a better purchase decision. This becomes even more viable in the context of online reviews as customers can not have the look and feel of the product as in the physical marketplace. These antecedents can help manufacturer and retailer to identify customer needs and influential points in a review. But there still remains aspects untouched in the literature as these antecedents do not have a clear business recommendation. Besides, there is limited contribution in terms of exploring and developing a prominent metric that can communicate review performance. Although Helpfulness percentage for a review indicates its influencing capability, further exploration might reveal factors that are not captured under helpfulness score.

From the implication section, the major contribution is the prominence of reviews. By this we mean, that how online reviews or its attributes affect tangible parameters like sales, profits, marketing mix etc. The validated importance of OCR and its implications indicate the scope of usage of its inferences by business. Review text is rich of various information about how a product is perceived, what are customer expectations and ultra-selling point of the product. Preference measurement models do find a place in the literature but there still remains a void to explore. An in-depth study of the review text can unpack several intricacies of the product that are either liked or disliked by the customers. Hence making such information vital for companies selling products online. Identification of patterns that can educate the e-commerce industry about customer preferences in terms of 
product or service would help optimize profits for the industry.

Besides text mining literature contributes in various ways in which review text can be analyzed. The methodological contribution with respect to analyzing text has been done for several domains of research a combination of these algorithmic ideas along with statistics or data mining methodologies can help in having a tangible conclusion from the review data analysis, which has not been significantly utilized in the management literature.

Utilization of knowledge from the assessment of OCR, its implications, and methodologies for analyzing text, in an integrated manner can lead to vital outcomes for both academia and industry. Literary gaps in various areas like a robust performance measure for Review's influencing capacity, its usage to derive prominent patterns that can help business identify customer choices and using methodologies suggested for text analysis, call for further research. Articulating future scope of research, the study concludes that there remains a need to have a recommendation model for business that can provide them tangible conclusion in terms of pattern, feature categorization or other details. This recommendation model can derive methodology from technology and management domains to build up a hybrid structure that can provide them a solution to business problems.

The suggested areas for further research has prominent implications for both academicians and managers. With the proliferated data on the virtual world, text constitutes a prominent section amongst available data forms. Future research can append academic contributions with knowledge creation from information extraction available in text form. Further, hybrid frameworks developed using both existing management and technology literature adds to ways in which analysis can be done.
Managers would get varied insight about customer preferences, orientation and attitude while making purchase decision on the online retail platform. Analytical framework also equip them to optimize outcome parameters of business.

\section{References}

Agarwal, S., Godbole, S., Punjani, D., \& Roy, S. R. S. (2007). How Much Noise Is Too Much: A Study in Automatic Text Classification. Seventh IEEE International Conference on Data Mining (ICDM 2007), 3-12. http://doi.org/10.1109/ICDM.2007.21.

Alexander, E., \& Morgera, D. (2014). On the Helpfulness of Analyzing Online Sentiments. Florida State University.

Anthuvan, K. K., Dhiviya, S., Rajeswari, C., \& Suguna, S. (2015). Real Time Based Opinion Mining of Product Reviews in Online Shopping Using Supervised Learning. International Journal of Advanced Research in Computer Engineering \& Technology (IJARCET), 4(2), 270-274.

Appel, O., Chiclana, F., \& Carter, J. (2015). Main Concepts, State of the Art and Future Research Questions in Sentiment Analysis. Acta Polytechnica Hungarica, 12(3), 87-108. http://doi. org/10.12700/aph.12.3.2015.3.6.

Aravindan, S., \& Ekbal, A. (2014). Feature Extraction and Opinion Mining in Online Product Reviews. In 2014 International Conference on Information Technology (pp. 94-99). http:// doi.org/10.1109/ICIT.2014.72.

Archak, N., Ghose, A., \& Ipeirotis, P. G. (2007). Show me the Money! Deriving the Pricing Power of Product. Proceedings of the 13th ACM SIGKDD International Conference on Knowledge Discovery and Data Mining - KDD '07, 56-65. http://doi. org/10.1145/1281192.1281202. 
Archak, N., Ghose, A., \& Ipeirotis, P. G. (2011). Deriving the Pricing Power of Product Features by Mining Consumer Reviews. Management Science, 57(8), 1485-1509. http:// doi.org/10.1287/mnsc. 1110.1370 .

Bae, S., \& Lee, T. (2011). Product type and consumers' perception of online consumer reviews. Electronic Markets, 21(4), 255-266. http://doi.org/10.1007 /s12525-011-0072-0.

Bafna, K., \& Toshniwal, D. (2013). Feature based Summarization of Customers' Reviews of Online Products. In Procedia Computer Science 22, 142 151. Elsevier Masson SAS. http:// doi.org/10.1016/j.procs.2013.09.090.

Bai, X. (2011). Predicting consumer sentiments from online text. Decision Support Systems, 50(4), 732-742. http: //doi.org/10.1016/j.dss.2010.08.024.

Bazeley, P. (2012). Regulating qualitative coding using QDAS? Sociological Methodology, 42(1), 77-78. http:// doi.org/10.1177/0081175012460852.

Blal, I., \& Sturman, M. C. (2014). The Differential Effects of the Quality and Quantity of Online Reviews on Hotel Room Sales. Cornell Hospitality Quarterly, 55(4), 365-375. http:// doi.org/10.1177/1938965514533419.

Bosman, D. (2013). The review credibility of electronic word-of-mouth communication on e-commerce platforms. Management Dynamics, 22(3), 29-45. Retrieved from http://reference.sabinet. co.za/sa_epublication_article/mandyn _v22_n3_a3.

Cao, H., \& Jiang, J. (2014). When Free Trials Meet Online Reviews: the Impact of Informativeness of Online Reviews and Perceived Quality homogeneity. PACIS., 351.
Cao, Q., Duan, W., \& Gan, Q. (2011). Exploring determinants of voting for the "helpfulness" of online user reviews: A text mining approach. Decision Support Systems, 50(2), 511-521. http://doi.org/10.1016/j.dss. 2010.11.009.

Casaló, L. V., Flavián, C., Guinalíu, M., \& Ekinci, Y. (2015). Avoiding the dark side of positive online consumer reviews: Enhancing reviews' usefulness for high risk-averse travelers. Journal of Business Research, 68(9), 1829-1835. http://doi.org/10.1016/j. jbusres.2015.01.010.

Chang, H. H., \& Wu, L. H. (2014). An examination of negative e-WOM adoption: Brand commitment as a moderator. Decision Support Systems, 59(1), 206-218. http://doi.org/10.1016 j.dss.2013.11.008.

Chatterjee, P. (2001). Please cite as: Online Reviews: Do Consumers Use Them? Patrali Chatterjee Faculty of Management Rutgers University Newark, NJ 07102-1897. ACR 2001 Proceedings, 129-134.

Chen, K. C. (2009). Text Mining eComplaints Data From e-Auction Store. Journal of Business, 7(5), 15-24.

Chen, P., \& Smith, M. D. (2001). All Reviews are Not Created Equal: The Disaggregate Impact of Reviews and Reviewers at Amazon.com.

Chen, Y., \& Xie, J. (2008). Online Consumer Review: Word-of-Mouth as a New Element of Marketing Communication Mix. Management Science, 54(3), 477-491. http://doi.org/10.1287 /mnsc.1070.0810.

Cheng, V., Rhodes, J., \& Lok, P. (2015). The Relationship between online reviews, brand trust, and willingness to buy. Strategic E-Commerce Systems and Tools for Competing in the Digital Marketplace, 139. http://doi.org /10.4018/978-1-4666-8133-0.ch007. 
Cheung, C. M. Y., Sia, C. L., \& Kuan, K. K. (2012). Is this review believable? A study of factors affecting the credibility of online consumer reviews from an ELM perspective. Journal of the Association for Information Systems, 13(8), 618 .

Cheung, C. M. K., \& Lee, M. K. O. (2012). What drives consumers to spread electronic word of mouth in online consumer-opinion platforms. Decision Support Systems, 53(1), 218-225. http://doi.org/10.1016/j.dss.2012.01.015.

Chevalier, J. a, \& Mayzlin, D. (2006). The Effect of Word of Mouth on Sales: Online Book Reviews. Journal of Marketing Research, 43(3), 345-354. http://doi.org/10.1509/jmkr.43.3.345.

Chou, C. H., Sinha, A. P., \& Zhao, H. (2008). A text mining approach to Internet abuse detection. Information Systems and E-Business Management, 6(4), pp. 419-439. http://doi.org/10.1007/ s10257-007-0070-0.

ComScore. (2007). Online ConsumerGenerated Reviews Have Significant Impact on Offline Purchase Behavior. Retrieved from http://www.comscore. $\mathrm{com} /$.

Conley, C., \& Tosti-Kharas, J. (2014). Crowdsourcing Content Analysis for Managerial Research. Management Decision, 52(4), 2. http://doi.org/10. 1108/MD-03-2012-0156.

Conway, M. (2006). The subjective precision of computers: A methodological comparison with human coding in content analysis. Journalism \& Mass Communication Quarterly, 83(1), pp. 186-200. http://doi.org/10.1177/ 107769900608300112.

Cui, G., Lui, H. K., \& Guo, X. (2012). The Effect of Online Consumer Reviews on New Product Sales. International Journal of Electronic Commerce, 17(1), 39-58. http://doi.org/10.2753 /JEC1086-4415170102.
Dellarocas, C., Awad, N., \& Zhang, X. (2004). Exploring the value of online reviews to organizations: Implications for revenue forecasting and planning. ICIS 2004 Proceedings, 30.

Dellarocas, C., \& Narayan, R. (2006, December). What motivates consumers to review a product online? A study of the product-specific antecedents of online movie reviews. In WISE (pp. 1-6).

Delloite. (2007, October). New Deloitte Study Shows Inflection Point for Consumer Products Industry; Companies Must Learn to Compete in a More Transparent Age. Press Release, Deloitte Services LP.

Devi, S., \& Kini, M. (2015). A Survey on Text Mining Approaches. International Journal of Combined Research \& Development (IJCRD), 4(2), 251-256.

Dichter, E. (1966). How word-of-mouth advertising works. Harvard Business Review. Retrieved from http://www. citeulike.org/group/328/article/1580011.

Dou, Y., \& Chen, J. (2015). Understanding the Value of Online Customer Reviews: The Channel Perspective. In PACIS (p. 182).

Duan, W., Gu, B., \& Whinston, A. B. (2008). Do online reviews matter? - An empirical investigation of panel data. Decision Support Systems, 45(4), pp. 1007-1016. http://doi.org/10.1016/j. dss.2008.04.001.

Engel, J., Blackwell, R., \& Miniard, P. (1995). Consumer behavior (8th eds.). Forth Worth-Tokyo: The Dryden Press,-992 $P p$.

Fan, M., \& Khademi, M. (2014). Predicting a Business Star in Yelp from Its Reviews Text Alone. arXiv Preprint Retrieved from http://arxiv.org/abs/ 1401.0864\%5Cnhttp://arxiv.org/ttp/arxi v/papers/1401/1401.0864.pdf. 
Filieri, R. (2014). What makes online reviews helpful? A diagnosticityadoption framework to explain informational and normative influences in e-WOM. Journal of Business Research, 68(6), 1261-1270. http:// doi.org/10.1016/j.jbusres.2014.11.006.

Floyd, K., Freling, R., Alhoqail, S., Cho, H. Y., \& Freling, T. (2014). How Online Product Reviews Affect Retail Sales: A Meta-analysis. Journal of Retailing, 90(2), 217-232. http://doi.org/10.1016 /j.jretai.2014.04.004.

Forman, C., Ghose, A., \& Wiesenfeld, B. (2008). Examining the Relationship Between Reviews and Sales: The Role of Reviewer Identity Disclosure in Electronic Markets. Information Systems Research, 19(3), 291-313. http://doi.org/10.1287/isre.1080.0193.

Ghode, M., Bere, S., Kamale, M., \& Moholkar, M. (2014). Sentiment Analysis over Online Product Reviews: A Survey. International Journal on Recent and Innovation Trends in Computing and Communication.

Ghose, A. (2007). Designing Novel Review Ranking Systems: Predicting Usefulness and Impact of Reviews Categories and Subject Descriptors. Comput. Intell., 1-7.

Ghose, A., \& Ipeirotis, P. G. (2007). Designing novel review ranking systems: predicting the usefulness and impact of reviews. ICEC 07 Proceedings of the Ninth International Conference on Electronic Commerce, pp. 303-310. http://doi.org/10.1145/ 1282100.1282158.

Ghose, A., \& Ipeirotis, P. G. (2011). Estimating the helpfulness and economic impact of product reviews: Mining text and reviewer characteristics. IEEE Transactions on Knowledge and Data Engineering, 23(10), 1498-1512. http://doi.org/ 10.1109/TKDE.2010.188.
Godes, D., Mayzlin, D., Chen, Y., Das, S., Dellarocas, C., Pfeiffer, B., ... \& Verlegh, P. (2005). The firm's management of social interactions. Marketing Letters, 16(3), 415428. Retrieved from http://www. springerlink.com/index/E400X743122 87377.pdf.

Goes, P. B., Lin, M. F., \& Yeung, C. M. A. (2014). "Popularity Effect" in UserGenerated Content: Evidence from Online Product Reviews. Information Systems Research, 25(2), 222-238. http://doi.org/10.1287/isre.2013.0512.

Gordon, G., Gu, B., \& Lin, M. (2006). The Dynamics of Online Consumer Reviews Guodong. Workshop on Information Systems and Economics (WISE), (2004), 1-6.

Gretzel, U. (2008). Use and Impact of Online Travel Reviews. Information and Communication Technologies in Tourism, 35-46.

Gu, B., Tang, Q., \& Whinston, A. B. (2013). The influence of online word-of-mouth on long tail formation. Decision Support Systems, 56(1), 474-481. http://doi.org/10.1016/j.dss.2012.11.004.

Guo, K., Wang, H., Song, Y., \& Du, Z. (2015). The effect of online reviews on e-tailers' pricing in a dual-channel market with competition. International Journal of Machine Learning and Cybernetics, 1-11. http://doi.org/10. 1007/s13042-015-0346-5.

Gupta, V., \& Lehal, G. S. (2009). A survey of text mining techniques and applications. Journal of emerging technologies in web intelligence, 1(1), pp. 60-76.

Halper, F. (2013). Text Analytics Hits the Mainstream. Business Intelligence Journal, 18(2), 29-34. 
Hao, Y. (2010). How does the Valence of Online Consumer Reviews Matter in Consumer Decision Making? Differences between Search Goods and Experience Goods, In Proceedings of the Annual Hawaii International Conference on System Sciences, 1-10.

He, W., Zha, S., \& Li, L. (2013). Social media competitive analysis and text mining: A case study in the pizza industry. International Journal of Information Management, 33(3), 464472. http://doi.org/10.1016/j.ijinfomgt. 2013.01.001.

Hennig-Thurau, T., Gwinner, K. P., Walsh, G., \& Gremler, D. D. (2004). Electronic word-of-mouth via consumer-opinion platforms: What motivates consumers to articulate themselves on the Internet? Journal of Interactive Marketing, 18(1), 38-52. http://doi.org/10.1002/dir.10073.

Hongwei, W., Wei, W., \& Pei, Y. (2014). Prodweakfinder: An information extraction system for detecting product weaknesses in online reviews based on sentiment analysis. In Proceedings - Pacific Asia Conference on Information Systems, PACIS 2014. Retrieved from http://www.scopus. $\mathrm{com} /$ inward/record.url?eid=2-s2.084928630878\&partnerID=tZOtx3y1.

Hu, M., \& Liu, B. (2006). Opinion extraction and summarization on the web. Aaai, 1-4. Retrieved from http://www.aaai. org/Papers/AAAI/2006/AAAI06-265.pdf.

Hu, N., Koh, N. S., \& Reddy, S. K. (2014). Ratings lead you to the product, reviews help you clinch it? The mediating role of online review sentiments on product sales. Decision Support Systems, 57, 42-53. http:// doi.org/10.1016/j.dss.2013.07.009.
Huang, A. H., Chen, K., Yen, D. C., \& Tran, T. P. (2015). A study of factors that contribute to online review helpfulness. Computers in Human Behavior, 48, 17-27. http://doi.org/10.1016/j.chb. 2015.01.010.

Hyrynsalmi, S., Seppänen, M., AarikkaStenroos, L., Suominen, A., Järveläinen, J., \& Harkke, V. (2015). Busting Myths of Electronic Word of Mouth: The Relationship between Customer Ratings and the Sales of Mobile Applications. Journal of Theoretical and Applied Electronic Commerce Research, 10(2), 1-18. http://doi.org/10.4067/S071818762015000200002.

Ingale, V. R., \& Phursule, R. N. (2014). Sentiment Analysis by Visual Inspection of User Data from Social Sites - A Review on Opinion Mining. International Journal of Science and Research, 3(12), 2188-2191.

Jiménez, F. R., \& Mendoza, N. A. (2013). Too popular to ignore: The influence of online reviews on purchase intentions of search and experience products. Journal of Interactive Marketing, 27(3), 226-235. http:// doi.org/10.1016/j.intmar.2013.04.004.

Kaiser, C., \& Bodendorf, F. (2012). Mining consumer dialog in online forums. Internet Research, 22(3), 275-297. http://doi.org/10.1108/1066224121123 5653.

Koh, N. S., Hu, N., \& Clemons, E. K. (2010). Do online reviews reflect a product's true perceived quality? An investigation of online movie reviews across cultures. Electronic Commerce Research and Applications, 9(5), pp. 374-385. http://doi.org/10.1016/j.ele rap.2010.04.001. 
Kronrod, A., \& Danziger, S. (2013). "Wii will rock you!" The use and effect of figurative language in consumer reviews of hedonic and utilitarian consumption. Journal of Consumer Research, 40(4), 726-739. http://doi. org/10.1086/671998.

Kwark, Y., Chen, J., \& Raghunathan, S. (2014). Online Product Reviews: Implications for Retailers and Competing Manufacturers. Information Systems Research, 25(1), 93. http://doi.org/10.1287/isre.2013.0511.

Lee, J., Park, D. H., \& Han, I. (2008). The effect of negative online consumer reviews on product attitude: An information processing view. Electronic Commerce Research and Applications, 7(3), 341-352. http://doi. org/10.1016/j.elerap.2007.05.004.

Lee, S., \& Choeh, J. Y. (2014). Predicting the helpfulness of online reviews using multilayer perceptron neural networks. Expert Systems with Applications, 41(6), 3041-3046. http:// doi.org/10.1016/j.eswa.2013.10.034.

Lerrthaitrakul, W., \& Panjakajornsak, V. (2014). The Impact of Electronic Word-of-Mouth Factors on Consumers' Buying Decision-Making Processes in the Low Cost Carriers: A Conceptual Framework. International Journal of Trade, Economics and Finance, 5(2), 142-146. http://doi. org/10.7763/IJTEF.2014.V5.357.

Lewis, S., Zamith, R., \& Hermida, A. (2013). Content Analysis in an Era of Big Data: A Hybrid Approach to Computational Manual Methods. Journal of Broadcasting \& Electronic Media, 57(1), 34-52. http://doi.org/10.1080/ 08838151.2012 .76170$.

Li, X., \& Hitt, L. M. (2008). Self-Selection and Information Role of Online Product Reviews. Information Systems Research, 19(4), 456-474. http://doi.org/10.1287/isre.1070.0154.
Li, X., \& Hitt, L. M. (2010). Price effects in online product reviews: An analytical model and empirical analysis. Mis Quaterly, 34(4), 809-831.

Li, X., Hitt, L. M., \& Zhang, Z. J. (2011). Product reviews and competition in markets for repeat purchase products. Journal of Management Information Systems, 27(4), 9-42.

Li, Y. M., Lin, C. H., \& Lai, C. Y. (2010). Identifying influential reviewers for word-of-mouth marketing. Electronic Commerce Research and Applications, 9(4), 294-304. http://doi.org/10.1016/ j.elerap.2010.02.004.

Liang, T. P., Li, X., Yang, C. T., \& Wang, M. (2015). What in Consumer Reviews Affects the Sales of Mobile Apps: A Multifacet Sentiment Analysis Approach. International Journal of Electronic Commerce, 20(2), 236-260. http://doi.org/10.1080/10864415.2016. 1087823.

Liu, Y., Huang, X., An, A., \& Yu, X. (2008). Modeling and Predicting the Helpfulness of Online Reviews. 2008 Eighth IEEE International Conference on Data Mining, 443-452. http:// doi.org/10.1109/ICDM.2008.94.

Liu, Z., Hong, L., \& Liu, L. (2014). An investigation of online review helpfulness based on movie reviews. African Journal of Business Management, 8(12), 441-450. http://doi.org/10.5897 /AJBM11.2628.

Liu, Z., \& Park, S. (2015). What makes a useful online review? Implication for travel product websites. Tourism Management, 47, 140-151. http://doi. org/10.1016/j.tourman.2014.09.020.

Lucas, C., Nielsen, R. A., Roberts, M. E., Stewart, B. M., Storer, A., \& Tingley, D. (2015). Computer-assisted text analysis for comparative politics. Political Analysis, 23(2), 254-277. 
Mauri, A. G., \& Minazzi, R. (2013). Web reviews influence on expectations and purchasing intentions of hotel potential customers. International Journal of Hospitality Management, 34, pp. 99107. http://doi.org/10.1016/j.ijhm.2013. 02.012

Minanovic, a, Gabelica, H., \& Krstic, Z. (2014). Big data and sentiment analysis using KNIME: Online reviews vs. social media. In Information and Communication Technology, Electronics and Microelectronics (MIPRO), International Convention on. IEEE (pp. 26-30). http://doi.org/10.1109/MIPRO. 2014.6859797.

Moon, S., Park, Y., \& Kim, Y. S. (2014). The impact of text product reviews on sales. European Journal of Marketing, 48(11/12), 2176-2197. http://doi.org/ 10.1108/EJM-06-2013-0291.

Moore, S. G. (2015). Attitude predictability and helpfulness in online reviews: The role of explained actions and reactions. Journal of Consumer Research, 42(1), 30-44. http://doi.org/10.1093/jcr/ucv003.

Mostafa, M. M. (2013). More than words: Social networks' text mining for consumer brand sentiments. Expert Systems with Applications, 40(10), 4241-4251. http://doi.org/10.1016/j. eswa.2013.01.019.

Ngai, E. W. T., Xiu, L., \& Chau, D. C. K. (2009). Application of data mining techniques in customer relationship management: A literature review and classification. Expert Systems with Applications, 36(2), 2592-2602. http:// doi.org/10.1016/j.eswa.2008.02.021.

Ngo-Ye, T. L., \& Sinha, A. P. (2014). The influence of reviewer engagement characteristics on online review helpfulness: A text regression model. Decision Support Systems, 61, 47-58. http://doi.org/10.1016/j.dss.2014.01.011.
Öğüt, H., \& Onur Taş, B. K. (2012). The influence of internet customer reviews on the online sales and prices in hotel industry. The Service Industries Journal, 32(2), 197-214. http://doi.org/ 10.1080/02642069.2010.529436.

Ojokoh, B. A. (2013). Generating Recommendation Status of Electronic Products from Online Reviews. Intelligent Control and Automation, 4(1), 1-10. http://doi.org/10.4236/ica.2013.41001.

Pan, L. Y., \& Chiou, J. S. (2011). How Much Can You Trust Online Information? Cues for Perceived Trustworthiness of Consumer-generated Online Information. Journal of Interactive Marketing, 25(2), 67-74. http://doi.org/10. 1016/j.intmar.2011.01.002.

Park, C., \& Lee, T. M. (2009). Antecedents of Online Reviews' Usage and Purchase Influence: An Empirical Comparison of U.S. and Korean Consumers. Journal of Interactive Marketing, 23(4), 332-340. http://doi. org/10.1016/j.intmar.2009.07.001.

Park, S., \& Nicolau, J. L. (2015). Asymmetric effects of online consumer reviews. Annals of Tourism Research, 50, pp. 67-83. http://doi.org/10.1016/j.annals. 2014.10.007.

Pavlou, P. A., \& Dimoka, A. (2006). The Nature and Role of Feedback Text Comments in Online Marketplaces: Implications for Trust Building, Price Premiums, and Seller Differentiation. Information Systems Research, 17(4), pp. 392-414. http://doi.org/10.1287/ isre.1060.0106.

Piller, C. (1999, December). "Everyone is a critic in cyberspace." Los Angeles Times, p. A1. Retrieved from http:// articles.latimes.com/1999/dec/03/new $\mathrm{s} / \mathrm{mn}-40120$. 
Purnawirawan, N., De Pelsmacker, P., \& Dens, N. (2012). Balance and Sequence in Online Reviews: How Perceived Usefulness Affects Attitudes and Intentions. Journal of Interactive Marketing, 26(4), 244-255. http: //doi.org/10.1016/j.intmar.2012.04.002.

Purnawirawan, N., Eisend, M., De Pelsmacker, P., \& Dens, N. (2015). A Meta-analytic Investigation of the Role of Valence in Online Reviews. Journal of Interactive Marketing, 31, 17-27. http://doi.org/10.1016/j.intmar. 2015.05.001.

Qazi, A., Syed, K. B. S., Raj, R. G., Cambria, E., Tahir, M., \& Alghazzawi, D. (2016). A concept-level approach to the analysis of online review helpfulness. Computers in Human Behavior, 58, 75-81. http://doi.org/10.1016/j.chb. 2015.12.028.

Raghupathi, D., Yannou, B., Farel, R., \& Poirson, E. (2015). Customer sentiment appraisal from user-generated product reviews: a domain independent heuristic algorithm. International Journal on Interactive Design and Manufacturing (IJIDeM), 9(3), 201211. http://doi.org/10.1007/s12008015-0273-4.

Revathi, S., Rajkumar, N., \& Sathish, S. (2015). A Text Sentimental Approach for Online Portals Using Hadoop. International Journal of Engineering Research and General Science, 3(1), 1023-1028.

Robinson, R., Goh, T. T., \& Zhang, R. (2012). Textual factors in online product reviews: A foundation for a more influential approach to opinion mining. Electronic Commerce Research, 12(3), 301-330. http://doi.org/ 10.1007/s10660-012-9095-7.
Salehan, M., \& Kim, D. J. (2015). Predicting the performance of online consumer reviews: A sentiment mining approach to big data analytics. Decision Support Systems, 81, 30-40. http://doi.org/10. 1016/j.dss.2015.10.006.

Sardesai, U., Makwana, A., \& Haria, S. (2014). Review Mining: A New Approach using Modified NLP. International Journal of Recent Technology and Engineering (IJRTE), 3(2), 87-90.

Schlosser, A. E. (2011). Can including pros and cons increase the helpfulness and persuasiveness of online reviews? The interactive effects of ratings and arguments. Journal of Consumer Psychology, 21(3), 226-239. http://doi. org/10.1016/j.jcps.2011.04.002.

Schneider, M. J., \& Gupta, S. (2016). Forecasting sales of new and existing products using consumer reviews: A random projections approach. International Journal of Forecasting, 32(2), pp. 243-256. http://doi.org/10.1016/ j.jforecast.2015.08.005.

Sen, S., \& Lerman, D. (2007). Why are you telling me this? An examination into negative consumer reviews on the web. Journal of Interactive Marketing, 21(4), 76-94. http://doi.org/10.1002/ dir.20090.

Severi, E., Ling, K. C., \& Nasermoadeli, A. (2014). The Impacts of Electronic Word of Mouth on Brand Equity in the Context of Social Media. International Journal of Business and Management, 9(8), 84-96. http://doi.org/10.5539/ ijbm.v9n8p84.

Shao, J. B., Li, Z. Z., \& Hu, M. Y. (2014, August). The impact of online reviews on consumers' purchase decisions in online shopping. In Management Science \& Engineering (ICMSE), 2014 International Conference on (pp. 287293). IEEE. 
Shen, Y., Li, S., \& Demoss, M. (2012). The effect of quantitative electronic word of mouth on consumer perceived product quality. International Journal of Management and Marketing Research, 5(2), 19-30. Retrieved from http:// ssrn.com/abstract=2145011.

Sidali, K. L., Schulze, H., \& Spiller, A. (2009). The impact of online reviews on the choice of holiday accommodations. Information and Communication Technologies in Tourism 2009, 87-98.

Simmons, L. L., Conlon, S., Mukhopadhyay, S., \& Yang, J. (2011). A computer aided content analysis of online reviews. Journal of Computer Information Systems, 52(1), 43-55.

Sparks, B. A., \& Browning, V. (2011). The impact of online reviews on hotel booking intentions and perception of trust. Tourism Management, 32(6), 1310-1323. http://doi.org/10.1016/j. tourman.2010.12.011.

Sparks, B. A., So, K. K. F., \& Bradley, G. L. (2016). Responding to negative online reviews: The effects of hotel responses on customer inferences of trust and concern. Tourism Management, 53, 74-85. http://doi.org/10. 1016/j.tourman.2015.09.011.

Sridhar Balasubramanian, V. M. (2001). The economic leverage of the virtual community. International Journal of Electronic Commerce, 5(3), 103-138. Retrieved from http://www.tandfonline. com/doi/abs/10.1080/10864415.2001. 11044212.

Strong, J., Ghosh, K., \& Conlon, S. (2008). Identifying Opportunities in Multilingual Business Environments Using Environmental Scanning and Text Mining Techniques. Journal of International Technology and Information Management, 17(3), 2.
Sundaram, D., Mitra, K., \& Webster, C. (1998). Word-of-mouth communications: A motivational analysis. Association for Consumer Research, 25, 527-531. Retrieved from http:// acrwebsite.org/volumes/8208/volumes /v25/NA-25.

Taboada, M., Brooke, J., Tofiloski, M., Voll, K., \& Stede, M. (2011). Lexicon-Based Methods for Sentiment Analysis. Computational Linguistics, 37(2), 267-307. http://doi.org/10.1162/COLI_a_00049.

Tan, L. K.W., Na, J.C., \& Theng, Y.L. (2011). Influence detection between blog posts through blog features, content analysis, and community identity. Online Information Review, 35(3), 425-442. http://doi.org/10.1108/1468 4521111151450.

Tang, C., \& Guo, L. (2015). Digging for gold with a simple tool: Validating text mining in studying electronic word-ofmouth (eWOM) communication. Marketing Letters, 26(1), 67-80. http:// doi.org/10.1007/s11002-013-9268-8.

Tang, H., Tan, S., \& Cheng, X. (2009). A survey on sentiment detection of reviews. Expert Systems with Applications, 36(7), 10760-10773. http://doi. org/10.1016/j.eswa.2009.02.063.

Thelwall, M., Buckley, K., Paltoglou, G., Skowron, M., Garcia, D., Gobron, S., ... Holyst, J. A. (2013). Damping sentiment analysis in online communication: Discussions, monologs and dialogs. Lecture Notes in Computer Science (Including Subseries Lecture Notes in Artificial Intelligence and Lecture Notes in Bioinformatics), 7817 LNCS(PART 2), 1-12. http://doi. org/10.1007/978-3-642-37256-8_1.

Tian, J., Chen, Y., \& Wang, L. (2014, June). Research on the Relationship between Online Reviews and Customer Purchase Intention: The Moderating Role of Personality Trait. In WHICEB (p. 1). 
Tian, Y. (2013). Engagement in online hotel reviews: A comparative study. Discourse, Context \& Media, 2(4), 184-191. http://doi.org/10.1016/j.dcm. 2013.10.002.

Trusov, M., Bucklin, R. E., \& Pauwels, K. (2010). Monetary Value of Word-ofMouth Marketing in Online Communities. Marketing Intelligence Review, 2(1), 26-34.

Tsur, O., Rappoport, A., \& Davidov, D. (2010). ICWSM - A Great Catchy Name: Semi-Supervised Recognition of Sarcastic Sentences in Online Product Reviews. International $A A A$ I Conference on Weblogs and Social Media, (9), 162-169.

Thet, T. T., Na, J. C., \& Khoo, C. S. G. (2010). Aspect-based sentiment analysis of movie reviews on discussion boards. Journal of Information Science, 36(6), 823-848. http://doi. org/10.1177/0165551510388123.

Webster, J., \& Watson, R. T. (2002). Analyzing the past to prepare for the future: Writing a literature review. MIS quarterly, 26(2), xiii-xxiii.

Wong, P. C., Whitney, P., \& Thomas, J. (1999). Visualizing association rules for text mining. In Proceedings 1999 IEEE Symposium on Information Visualization (InfoVis'99) (p. 120123,). http://doi.org/10.1109/INFVIS. 1999.801866 .

Wu, J., \& Gaytán, E. A. A. (2013). The role of online seller reviews and product price on buyers' willingness-to-pay: a risk perspective. European Journal of Information Systems, 22(4), 416-433. http://doi.org/10.1057/ejis.2012.33.

Wulff, J., \& Hardt, D. (2014). Can You Trust Online Ratings ? Evidence Of Systematic Differences In User Populations, $0-12$.
Xiang, Z., Schwartz, Z., \& Uysal, M. (2015). What types of hotels make their guests (un) happy? Text analytics of customer experiences in online reviews. Information and Communication, 33-45. Retrieved from http://link. springer.com/chapter/10.1007/978-3319-14343-9_3.

Xiao, S., Wei, C. P., \& Dong, M. (2016). Crowd intelligence: Analyzing online product reviews for preference measurement. Information \& Management, 53(2), 169-182. http://doi.org/10. 1016/j.im.2015.09.010.

Ye, Q., Zhang, Z., \& Law, R. (2009). Sentiment classification of online reviews to travel destinations by supervised machine learning approaches. Expert Systems with Applications, 36(3), 6527-6535. http://doi.org/10. 1016/j.eswa.2008.07.035.

You, W., Xia, M., Liu, L., \& Liu, D. (2012). Customer knowledge discovery from online reviews. Electronic Markets, 22(3), 131-142. http://doi.org/10. 1007/s12525-012-0098-y.

Yu, X., \& Liu, Y. (2012). Mining Online Reviews for Predicting Sales Performance: A Case Study in the Movie Domain. IEEE Transactions on Knowledge and Data Engineering, 24(4), 720-734.

Zhang, K. Z. K., Zhao, S. J., Cheung, C. M. K., \& Lee, M. K. O. (2014). Examining the influence of online reviews on consumers' decision-making: A heuristic-systematic model. Decision Support Systems, 67, 78-89. http:// doi.org/10.1016/j.dss.2014.08.005.

Zhang, W., Xu, H., \& Wan, W. (2012). Weakness Finder: Find product weakness from Chinese reviews by using aspects based sentiment analysis. Expert Systems with Applications, 39(11), 10283-10291. http://doi.org/ 10.1016/j.eswa.2012.02.166. 
Zheng, L., Wang, H., \& Gao, S. (2015). Sentimental feature selection for sentiment analysis of Chinese online reviews. International Journal of Machine Learning and Cybernetics, 1-10. http://doi.org/10.1007/s13042015-0347-4.

Zheng, X., Zhu, S., \& Lin, Z. (2013). Capturing the essence of word-ofmouth for social commerce: Assessing the quality of online ecommerce reviews by a semisupervised approach. Decision Support Systems, 56(1), 211-222. http:// doi.org/10.1016/j.dss.2013.06.002.

Zhou, W., \& Duan, W. (2015). An empirical study of how third-party websites influence the feedback mechanism between online Word-of-Mouth and retail sales. Decision Support Systems, 76, 14-23. http://doi.org/10.1016/j.dss. 2015.03.010.

Zhu, F. (2010). Impact of Online Consumer Reviews on Sales: The Moderating Role of Product. Journal of Marketing, 74(2), 133-148.

Zhu, F., \& Zhang, X. (2006). The Influence of Online Consumer Reviews on the Demand for Experience Goods: The Case of Video Games. ICIS 2006 Proceedings, 25.

Zhu, M., \& Fang, X. (2014, April). What nouns and adjectives in online game reviews can tell us about player experience?. In Proceedings of the extended abstracts of the 32nd annual ACM conference on Human factors in computing systems (pp. 1471-1476). ACM. http://doi.org/10.1145/2559206. 2589648.

Zhuang, L., Jing, F., \& Zhu, X. Y. (2006). Movie Review Mining and Summarization. In Proceedings of the 15th ACM international conference on Information and knowledge management. (pp. 43-50).

\section{About the Authors}

Ms. Oshin Anand: Research Scholar, Fellow Programme in Management in IT systems area. Oshin Anand works in the domain of data and text analysis on online platforms, for business recommendations and has conference and journal publications on online purchase intention and online Reviews.

Dr. Praveen Ranjan Srivastava is a faculty in the Area of Information Technology Systems at IIM Rohtak. He did his Ph.D. in Computer Science \& Engineering from Birla Institute of Technology \& Science, Pilani. During Ph.D. tenure he got various fellowship and awards from leading organizations like Google, Microsoft. He is currently doing research in the area of Data analytics, E-commerce \& software engineering using nature inspired techniques. His research areas are software testing management, Analytics and $E$ commerce, Software Project Management, Quality assurance, Agile Modeling \& Management etc. $\mathrm{He}$ has published research papers in various leading international journals and conferences in the area of Information System/Computer science and engineering. His $H$ index is 15 and I index is 24 . He has been actively involved in reviewing various research papers submitted in his field to different leading journals and various international and national level conferences

Dr. Atanu Rakshit has earned his Ph.D. degree in Computer Science from Calcutta University in 1984. He has more than 32 years of Teaching, Research and Consulting experience in the area of Information Technology. His research interest includes Business Analytic, Cloud Computing, Business Process Management, Service Oriented Architecture, Enterprise Application Integration, Data Warehousing and Data Mining. Dr. Rakshit is actively involved in providing consulting services to various areas of E- Security, E-Business, ECommerce, Total Network Solution, Application Software Development, BPR 
anand et al.: Assessment, Implication, and Analysis of Online Consumer Reviews:

Assessment, Implication, and Analysis of Online Consumer Reviews / Anand et al.

through IT, System Integration. He is Fellow of Computer Society of India and has published many papers in the International/ National Journals and Conferences. He has chaired many International Conferences in India and abroad. He is the reviewer of International journals in UK and USA. Dr. Rakshit is the member of IEEE. 